\title{
Changes in Electrical Engineering Programs for an Energy Sustainability Inclusive Degree
}

\author{
Christopher Reyes-Lopez, M.E. ${ }^{1}$, and Elier Gonzalez-Martinez, M.S. ${ }^{1}$ \\ 1Universidad Politecnica Salesiana, Ecuador, creyesl@ups.edu.ec, egonzalez@ups.edu.ec
}

\begin{abstract}
After suffering some consequences of global warming over the last decades, governments have been adopting different approaches for the sustainable development of nations. Thus, universities have had to adapt their programs to the requirements of the market. This article responds to the need of knowing what Ecuadorian universities think about the modifications in the curricula of electrical engineering programs, such as the inclusion of renewable energy courses. To achieve this goal, the project surveys a representative of ten participant universities. The outcomes show that although most programs have updated their curriculum, they do not count with the necessary resources to teach specialized courses on energy sustainability for the proper formation of future professionals possessing the competences required by the current national energy exploitation scene.
\end{abstract}

Keywords-curriculum update, energy market needs, globalized education, learning activities, undergraduate education.

Resumen-Tras sufrir algunas consecuencias del calentamiento global en las últimas décadas, los gobiernos han estado adoptando enfoques diferentes para el desarrollo sostenible de las naciones. Por lo que, las universidades han tenido que adaptar sus programas a los requerimientos del mercado. Este artículo responde a la necesidad de conocer lo que las universidades ecuatorianas piensan acerca de las modificaciones en los currículos de los programas de ingeniería eléctrica, tal como la inclusión de cursos de energías renovables. Para alcanzar este objetivo, el proyecto encuesta a un representante de las diez universidades participantes. Los resultados muestran que, aunque la mayoría de los programas ha actualizado sus currículos, estos no cuentan con los recursos necesarios para impartir cursos especializados en sustentabilidad energética para la formación apropiada de futuros profesionales que posean las competencias requeridas en el escenario actual de la explotación energética nacional.

Palabras clave-actividades de aprendizaje, actualización curricular, educación de pregrado, educación globalizada, necesidades del mercado energético.

\section{INTRODUCTION}

In order to achieve the national energy sustainability, the Ecuadorian Government has bet on projects that incorporate renewable energies (RE) into the conventional network for the efficient generation of electricity [1]. Such projects require qualified engineers capable of planning, installing and tuning hybrid energy systems [2].

As the study [3] states, the knowledge and potential of new engineers highly depends on what they have learnt along their higher education. For instance, many electrical engineering undergraduate programs (EE) lack energy sustainability and sustainable development (RE\&SD) courses in their study plans [4], [5], what may lead to significant differences between students from one university to another.

Digital Object Identifier (DOI):

http://dx.doi.org/10.18687/LACCEI2019.1.1.65

ISBN: 978-0-9993443-6-1 ISSN: 2414-6390
Around the world, several higher education institutes have acknowledged the importance of sustainability and transdisciplinary understanding [6]. A study even demonstrates the vital role of teaching engineering students the importance of sustainability through environmental, technological, ethical, social and economic aspects that will favor their professional development complemented with a sustainable culture [7].

The knowledge society cannot be fully conceptualized without thinking of higher education. Universities are spaces for research, development and innovation $(R \& D+i)$, in other words: knowledge sharing. $R \& D+i$ are indispensable for social and economic development of nations, and the improvement of life quality consequently [8].

Moreover, engineering students themselves believe that the inclusion of environmental, social, economic and cultural dimensions are relevant to their education [9]. They think such topics are useful to develop a holistic understanding of their field but specially to have an advanced real-world learning.

Furthermore, different principles of modern education, such as contextual, collaborative and experiential learning, contemplate the needs of the ever-changing electrical engineering field [10]. For this reason, lecturers are using new approaches, such as problem-based learning, thought for a comprehensive and practical education.

Studies research the effects of learning activities on student's performance. Via a principal component analysis, One of them recognizes the high correlation between the final grades of engineering students and classroom and alternative learning activities, even giving the possibility of abolishing the final cumulative exams [11]. Another one states the authors' idea to permit undergraduates to choose experiential courses that differ from typical major courses in order to involve them in diverse real work environments [12].

All the aspects reviewed so far are part of the reasons that have led various universities to update the curricula [13], [14]. The frequent evaluation and update of curriculum ensure that undergraduate programs support the mission and vision of higher education institutions while following the guidelines set by national governments. They also facilitate to take academic programs towards a globalized education [15].

Curricula are usually assessed through surveys and interviews carried out among the students. Nevertheless, these approaches do not provide undergraduates with a curriculum model useful as a guideline throughout their educational process. Hence, a study considers data mining to create the curriculum model based on students' academic results [16].

The evaluation of a curriculum usually allows to determine positive modifications of its content that could improve the students' learning process. Erkan and Rouyendegh found that 
multicriteria decision making modeling can be used for the optimal design and planning of industrial engineering curricula and suggested it in their project carried out in Turkey [17].

A project in Saudi Arabia offers a software engineering curricula development and assessment process considering the local software market requirements and the undergraduate program objectives and constraints. It benefits of the ISO/IEC 19759 standard to enrich such program based on objective and subjective facts. It detects weaknesses of the curricula and discovers factors that possibly help mitigate skill deficiencies in the software market [18].

Complex system modeling in combination with distributed agency and fuzzy inference systems has been used by the Autonomous University of Baja California for curricular design. Such methodology, besides being useful for the planning of a undergraduate program structure, contributes to the development of the knowledge society up to a point [8].

As reviewed, different studies propose methodologies for curriculum assessment and modification. As for Ecuador, several universities have updated their EE curriculum to try to form future electrical engineers with specialized technological knowledge of renewable energy based on the requirements of the national energy market.

In this context, this paper aims to assess the preparation of Ecuadorian universities to add RE\&SD in the EE curricula. This assessment is carried out via a survey that includes questions about technological infrastructure, lecturers' career and educational strategies. It means, instead of revising the conventional classroom schooling, it evaluates alternative methods used for the student's progress.

The following section of this manuscript is Materials and Methods, which introduces the sample selection and the questionnaire developed for this study. After that, the Results section explains how changes adopted by electrical engineering departments prepared them to impart RE\&SD courses through statistical analysis. Finally, authors put forward some discussions about the findings, as well as further research and conclusions.

\section{MATERIALS AND METHODS}

The Ecuadorian Master Plan of Electrification (MPE) is an integral and intersectoral tool that promotes the utilization of renewable resources to guarantee the supply of the national energy demand, ensuring appropriate security, reliability and quality levels under technic, economic, social and environmental criteria [19].

After the content analysis of the long-term policies of the MPE, it was possible to determine six central components: renewable energy, economic conscience, environmental responsibility, social sense, knowledge sharing (research, development and innovation) and country development (progress and well-being). It is important to remark that several recording units might represent a specific component [20], for instance, green energy signifies renewable energy.

Ecuador counts 55 institutions of higher education, classified in categories A, B and C based on the assessment performed by the Council for the Evaluation, Accreditation and Quality Assurance of Higher Education (CEAACES, for its acronym in Spanish) [21]. Eleven universities offer EE but only ten are considered because of their participation in the survey, three of category A, four of category B and three of category C.

The list of participants in alphabetical order is: Escuela Politecnica Nacional [22], Escuela Superior Politecnica del Litoral [23], Universidad Catolica de Cuenca [24], Universidad de Cuenca [25], Universidad Laica Eloy Alfaro de Manabi [26], Universidad Politecnica Salesiana [27], Universidad Tecnica de Cotopaxi [28], Universidad Tecnica de Manabi [29], Universidad Tecnica Estatal de Quevedo [30] and Universidad Tecnica Luis Vargas Torres [31].

TABLE I

QUESTIONNAIRE ON LEARNING COMPONENTS OF THE PROGRAM

\begin{tabular}{|c|c|}
\hline Item & Question \\
\hline Q1 & $\begin{array}{l}\text { The department prepared the program considering objectives of the } \\
\text { Master Plan of Electrification. }\end{array}$ \\
\hline Q2 & $\begin{array}{l}\text { The department has agreements with energy public or private } \\
\text { companies and regulatory entities. }\end{array}$ \\
\hline Q3 & $\begin{array}{l}\text { The department encourages students to get involved in research } \\
\text { and writing scientific papers. }\end{array}$ \\
\hline Q4 & $\begin{array}{l}\text { The department organizes conferences based on research, } \\
\text { development and innovation. }\end{array}$ \\
\hline Q5 & $\begin{array}{l}\text { The department counts with appropriate technology for renewable } \\
\text { energy laboratories. }\end{array}$ \\
\hline Q6 & $\begin{array}{l}\text { The department periodically organizes talks with industry } \\
\text { professionals in campus and field trips. }\end{array}$ \\
\hline Q7 & $\begin{array}{l}\text { The department makes students recognize the environmental } \\
\text { responsibility and conducts projects that make them commit to the } \\
\text { reduction of the environmental load. }\end{array}$ \\
\hline Q8 & $\begin{array}{l}\text { The department conducts projects that engage students in } \\
\text { promoting better conditions and social justice for unfavored } \\
\text { communities and minorities. }\end{array}$ \\
\hline Q9 & $\begin{array}{l}\text { The department conducts local development projects that involve } \\
\text { students in making possible the improvement of the beneficiaries' } \\
\text { economic condition. }\end{array}$ \\
\hline Q10 & $\begin{array}{l}\text { Percentage of lecturers owning degrees in the renewable energy } \\
\text { field. }\end{array}$ \\
\hline Q11 & $\begin{array}{l}\text { Percentage of lecturers having expertise in the renewable energy } \\
\text { field. }\end{array}$ \\
\hline Q12 & $\begin{array}{l}\text { Percentage of lecturers owning degrees in the sustainable } \\
\text { development or sustainability fields. }\end{array}$ \\
\hline Q13 & $\begin{array}{l}\text { Percentage of lecturers having expertise in the sustainable } \\
\text { development or sustainability fields. }\end{array}$ \\
\hline Q14 & $\begin{array}{l}\text { Lecturers involve students in solving situations of real-life } \\
\text { electrical engineering projects. }\end{array}$ \\
\hline Q15 & $\begin{array}{l}\text { Lecturers promote design thinking, project-based and other } \\
\text { contextual learning methods in classes. }\end{array}$ \\
\hline
\end{tabular}


This project mainly consists of a survey conducted to a representative of every EE program in Ecuador. It uses a fifteen-item questionnaire, shown in table 1, that evaluates the learning components employed for the addition of the six MPE components into the new curricula.

It includes questions about the introduction of innovative approaches for the improvement of the student's performance in a dynamic fashion. Contextual and experiential learning are among those methodologies used by high-ranked universities with leading education.

On the one hand, contextual learning facilitates the student's learning through the use of design thinking, projectbased and maker-based activities [15]. On the other hand, experiential learning involves students into real projects, frequently executed out of the university, to develop their professional skills [32].

The questionnaire follows a nine-point Likert scale. The values of the scale for questions one to nine and, questions fourteen and fifteen correspond to 1-Totally disagree, 2-Very disagree, 3-Moderately disagree, 4-Slightly disagree, 5-Neither agree nor disagree (neutral point), 6-Slightly Agree, 7Moderately agree, 8 -Very agree, and 9-Totally agree.

Questions 10 through 13 have different values since they measure percentages. In these cases, the scale goes from $0 \%$ for the first point, point 2 is $2.5 \%$, point 3 is $5 \%$, point 4 is $7.5 \%$, point 5 is $10 \%$, point 6 is $12.5 \%$, point 7 is $15 \%$, point 8 is $17.5 \%$, and reaches a maximum of $20 \%$ for point 9 .

\section{RESULTS}

Every Department of Electrical Engineering was asked for answering only one questionnaire through common consensus, i.e. this study counts with ten data sets for statistical processing. After a first analysis, it denotes that the questionnaire has a high reliability, which has been defined by a Cronbach's alpha of 0.938 .

In general, the recorded values will help measure, to some extent, what the departments think about the readiness of the university to offer the EE program after the curricular modification. It is important to remark that universities updated its curriculum and learning components not only based on the national energy demands but taking into consideration its local reality as well.

According to the outcomes, all the EE departments consider they are fairly succeeding the adaptation to new curricula. This means, they have analyzed the changes of the energy matrix, establishing the new courses and learning components based on the guidelines of the MPE. As expected, category A universities have the highest scores of the survey, with the Escuela Politecnica Nacional heading the list.

The comprehensive compilation of the data collected during the survey allowed to perform a national assessment. The boxplot in figure 1 allowed to understand whether programs overcome the curricular changes.

The category RE comprises questions Q5, Q10 and Q11. Q5 shows that half the participants disagree on having appropriate technology to offer RE courses, while the other half partially disagrees tending to neutrality. Q10 and Q11 indicate a maximum of $10 \%$ and $7.5 \%$ of lecturers owning degrees and experience in RE fields, respectively. The percentage of faculty capable of teaching RE courses is very low in average. It demonstrates the country is not yet prepared to offer RE courses.

Sustainable development simultaneously involves economic conscience, environmental responsibility and social sense since it has been defined as reaching the objectives and comfort of human development, keeping up the environment capacity to supply natural resources on what modern society and world economy rely upon [33].

For this reason, Q12 and Q13 are interpreted first, to indicate the level of preparation of lecturers to teach sustainable development subjects. Three quarters of respondents confirmed that up to $5 \%$ of lecturers owns degrees on sustainable development; whereas all confirmed that up to $5 \%$ has such expertise. Their levels are even lower than for RE.

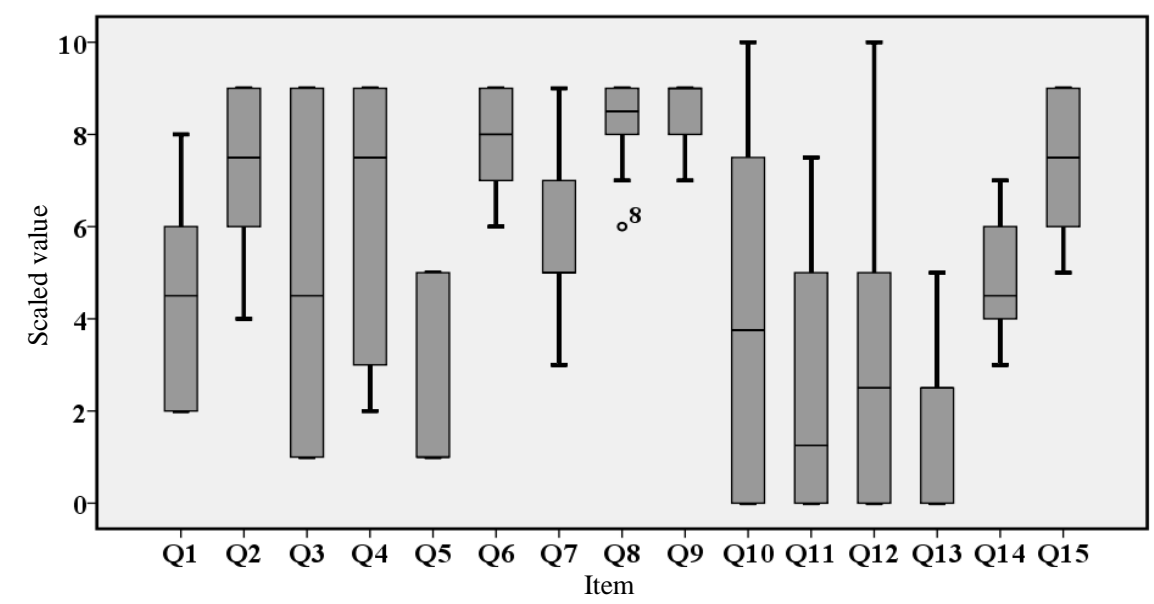

Figure 1 - National findings of the survey on technological infrastructure, lecturers' career and educational strategies

$17^{\text {th }}$ LACCEI International Multi-Conference for Engineering, Education, and Technology: "Industry, Innovation, And Infrastructure for Sustainable Cities and Communities", 24-26 July 2019, Jamaica. 
According to Q9 outcomes, respondents consider that their department works hard to educate Economic conscience in practical and experiential approaches. They promote the active participation of students in projects that make possible to improve the economic condition of recipients.

In the case of instilling Environmental responsibility, Q7 outcomes depict half of respondents somewhat agreeing on the department taking the necessary measures to achieve this goal. A quarter partially disagrees, and the other quarter is unsure. Giving a not so good picture of this category.

Concerning Social Sense, half the participants agree on the participation of the department in conducting projects engaging students in social services to benefit the collective, and the student themselves inherently, as seen for Q8. An atypical value is introduced but its dispersion is not too high to affect the results.

Q15, in category Knowledge sharing, reveals the common attention of Ecuadorian universities, mainly category A, to introduce alternative ways of learning. Contextual learning has demonstrated to be an outstanding practice for engineering education [34]. In this context, Q6 exhibits a high interest of the programs in sharing professionals' experience through talks and field trips.

Contrarily, Q4 exhibits that $60 \%$ of respondents thinks they share their findings and update their knowledge of development and innovation through events gathering academia and industry, the rest hardly disagrees. Based on Q3 outcomes, category A universities encourage students to get involved in research and scientific production. A quarter of the participants totally disagrees, and the remains lie dispersed in between.

The remaining three questions conform category Country development. Q1 discloses that over half of the participants confirms their programs were updated without taking into account the MPE guidelines to fulfill the national energy requirement.

As expected, Q2 outcomes explain that universities have at least one agreement with energy companies and regulators, reflecting their disposition to participate in country development. This is vital to generate local and national projects that drive the country progress and wellbeing, becoming an opportunity for experiential learning in the classrooms as well. In this framework, Q14 outcomes show that lecturers are able to involve students in real life projects. Fairly above $25 \%$ of universities make their students participate in industry projects, linking them to the professional field.

In addition, some of the correlations, obtained from the correlation matrix with a determinant of 0.06 , between two attributes are presented to revalidate the results, e.g. if the department counted with appropriate technology for renewable energy laboratories, it would encourage students to get involved in research and scientific writing, confirmed by a Pearson correlation (r) value of 0.861 , with a significance level (p) of 0.001 .

The involvement of students in industry projects relies upon the agreements between the Department and energy companies and regulators $(\mathrm{r}=0.665, \mathrm{p}=0.016)$. And, it is very likely that lecturers owning degrees in a specific field also have expertise in such field. The correlations are $0.819(\mathrm{p}=0.004)$ and $0.898(\mathrm{p}=0.000)$ for RE and SD, respectively. Additionally, the percentage of RE lecturers will depend on the examination of the MPE objectives by the Department ( $\mathrm{r}=0.845, \mathrm{p}=0.002)$.

TABLE 2 THE ROTATED COMPONENT MATRIX

\begin{tabular}{|c|c|c|c|c|}
\hline Item & 1 & 2 & 3 & 4 \\
\hline Q1 & ,878 & & & \\
\hline Q2 & ,784 & & & \\
\hline Q3 & & & &, 820 \\
\hline Q4 & & & & ,809 \\
\hline Q5 & & & 891 & \\
\hline Q6 & & & & 961 \\
\hline Q7 & & 663 & & \\
\hline Q8 & & 684 & & \\
\hline Q9 & & ,702 & & \\
\hline Q10 & & & 853 & \\
\hline Q11 & & & 900 & \\
\hline Q12 & & ,857 & & \\
\hline Q13 & & 854 & & \\
\hline Q14 & ,772 & & & \\
\hline Q15 & & & & ,852 \\
\hline
\end{tabular}

Extraction method: Principal components analysis. Rotation method: Varimax with Kaiser normalization. The rotation has converged in 34 iterations

Additionally, the six components were validated through a principal components analysis and a factor analysis using Kaiser-Meyer-Olkin test $(\mathrm{KMO}=0.894, \mathrm{p}=0.000)$. Table 2 shows the values for the rotated component matrix. As expected, the matrix found four components: renewable energy, knowledge sharing, country development and a mix of economic conscience, environmental responsibility and social sense, what may be called 'sustainable development'.

\section{DISCUSSIONS}

As reviewed, interviews and surveys addressed to students are not always the best way to assess the effectiveness of the curriculum as the guidelines for educational process. And, although Priyambada et al. successfully used data mining for designing a curriculum model based on the academic grades of 
the participant students [16], the result is not mandatorily the more effective curriculum.

For this reason, this study considered the comments of the department of electrical engineering of the ten participants to understand whether Ecuadorian universities are really succeeding the inclusion of MPE objectives and the needs of the energy market.

In Malaysia, higher education institutes must include entrepreneurship instruction in their academic programs by royal decree [35]. Undergraduates are encouraged to start their own enterprises, since the country wants professionals that create jobs rather than looking for one.

Current studies identify the needs for new strategies to include sustainability in engineering education [36]. All, including this one, propose to integrate faculty's sustainability knowledge into the technological courses.

It is important to remark that new approaches must be implemented in curriculum, for instance the educational variant that lets students choose experiential courses that differ from their major, proposed by Fardoun et al. [12]. Any experiential course that allows undergraduates to be involved in real work environments will positively affect student's development.

This type of courses should be offered in Ecuadorian EE programs. Additionally, a positive change of such proposal will be the sign of official working-learning contracts regulated under mutual agreement of the university and the enterprise.

Another consideration to be taken into account is the inclusion of m-learning to diversify the courses offered and to improve the student's time. Different methods might be used to identify whether students are up to taking this type of courses, such as focus groups and interviews. A study shows the raising inclination for mobile devices and the implementation of $\mathrm{m}$ learning in the teaching and learning processes [37].

While in Ecuador most universities are incorporating sustainability-related courses to update the curriculum of EE programs, many universities around the world are offering new engineering programs in the field of energy [5].

For instance, the Holon Institute of Technology in Israel offers the RE program. This program provides students with theoretical and practical concepts of energy generation, including conventional and unconventional sources, as well as its environmental impacts [38].

Nonetheless, the curricula are one of the key factors to determine the quality of undergraduate programs and their impact on electrical engineering market. Thus, the development and innovations introduced should be properly assessed before being implemented. [39], [40].

Additionally, the effects of evaluation methodologies for the lately implemented educational strategies should be revised since new didactics might affect curricular paradigm. Design and implementation of evaluation is the main element of instruction process [41].

\section{CONCLUSION}

This paper suggests a criterion to assess the modifications performed to the curriculum of EE programs in Ecuador. The questionnaire was validated through statistical analysis. Such criterium evaluates the design of curricula from the point of view of the department of EE of every Ecuadorian university.

According to the outcomes, the six components identified from the MPE were accomplished to some extent by every participant. It means, the new curricula partially comply with the MPE objectives, and consequently with the requirements of the energy market. Hence, further action is necessary, such as qualifying lecturers in RESSD, implementing teaching strategies and developing courses that incorporate contextual and experiential learnings.

The study indicates that in order to achieve a comprehensive renewable energy knowledge is not necessary to add diverse courses to the curriculum but offering a new program instead. Ergo, new engineering programs would help stop the existing deficiency in energy engineering education and provide future engineers with crucial skills to support Ecuador's energy matrix transformation.

\section{REFERENCES}

[1] J. Lata-García, C. Reyes-Lopez, and F. Jurado, "Attaining the Energy Sustainability: Analysis of the Ecuadorian Strategy Ku zrównoważoności energetycznej: analiza Strategii Ekwadorskiej," Probl. ekorozwoju / Probl. Sustain. Dev., vol. 13, no. 1, pp. 21-29, 2018.

[2] M. C. Felgueiras, J. S. Rocha, and N. Caetano, "Engineering education towards sustainability," Energy Procedia, vol. 136, pp. 414-417, 2017.

[3] M. Thürer, I. Tomašević, M. Stevenson, T. Qu, and D. Huisingh, “A Systematic Review of the Literature on Integrating Sustainability into Engineering Curricula," J. Clean. Prod., vol. 181, pp. 608-617, 2017

[4] J. O. Jaber et al., "Renewable energy education in faculties of engineering in Jordan: Relationship between demographics and level of knowledge of senior students'," Renew. Sustain. Energy Rev., vol. 73, no. February 2016, pp. 452-459, 2017.

[5] F. J. Lozano and R. Lozano, "Developing the curriculum for a new Bachelor's degree in Engineering for Sustainable Development," J. Clean. Prod., vol. 64, pp. 136-146, 2014.

[6] M. Hammer and T. Söderqvist, "Enhancing transdisciplinary dialogue in curricula development," Ecol. Econ., vol. 38, no. 1, pp. 1-5, 2001.

[7] F. O. Machín Armas, S. G. Céspedes Montano, A. N. Riverón Mena, and E. Fernández Santiesteban, "Sostenibilidad, ingeniería y enseñanza de las ciencias básicas . Marco teórico conceptual," Rev. Iberoam. Educ., vol. 73, pp. 179-202, 2017.

[8] E. Ahumada-Tello and M. Castanon-Puga, "Modelling complex systems with distributed agency and fuzzy inference systems. Knowledge-based curricula in higher education," Procedia Comput. Sci., vol. 80, pp. 2317-2321, 2016.

[9] S. Sivapalan, "Sustainability, blended learning and the undergraduate communication skills classroom: negotiating engineering undergraduates' expectations and perceptions," Horiz., vol. 25, no. 1, pp. 7-23, 2017.

[10] A. Guerra, "Integration of sustainability in engineering education," Int. J. Sustain. High. Educ., vol. 18, no. 3, pp. 436-454, 2017.

[11] R. Ramirez-Velarde, N. Alexandrov, M. Sanhueza-Olave, and R. Perez-Cazares, "The impact of learning activities on the final grade in engineering education," Procedia Comput. Sci., vol. 80, pp. $1812-1821,2016$.

H. M. Fardoun, A. P. Cipres, and D. M. Alghazzawi, "Centralizing Students Curriculums to the Professional Work,” Procedia - Soc.

$17^{\text {th }}$ LACCEI International Multi-Conference for Engineering, Education, and Technology: "Industry, Innovation, And Infrastructure for Sustainable Cities and Communities", 24-26 July 2019, Jamaica. 
Behav. Sci., vol. 122, pp. 373-380, 2014.

[13] R. Lozano, "Diffusion of sustainable development in universities' curricula: an empirical example from Cardiff University," J. Clean. Prod., vol. 18, no. 7, pp. 637-644, 2010.

[14] J. Padgham, H. Virji, and C. Seipt, "Promoting climate change curricula development in African universities," Environ. Dev., vol. 5, no. 1, pp. 169-171, 2013.

[15] M. Durišová, A. Kucharčíková, and E. Tokarčíková, "ScienceDirect Assessment of higher education teaching outcomes (Quality of higher education)," Procedia -Social Behav. Sci., vol. 174, pp. 2497-2502, 2015.

[16] S. A. Priyambada, E. R. Mahendrawathi, and B. N. Yahya, "Curriculum Assessment of Higher Educational Institution Using Aggregate Profile Clustering," Procedia Comput. Sci., vol. 124, pp. 264-273, 2017.

[17] T. E. Erkan and B. D. Rouyendegh, "Curriculum Change Parameters Determined by Multi Criteria Decision Making (MCDM)," Procedia - Soc. Behav. Sci., vol. 116, no. 1987, pp. 1744-1747, 2014.

[18] A. Alarifi, M. Zarour, N. Alomar, Z. Alshaikh, and M. Alsaleh, "SECDEP: Software engineering curricula development and evaluation process using SWEBOK," Inf. Softw. Technol., vol. 74, pp. 114-126, 2016.

[19] Ministry of Electricity and Renewable Energy, "Executive Summary," Quito, 1, 2013.

[20] M. Bengtsson, "How to plan and perform a qualitative study using content analysis," NursingPlus Open, vol. 2, pp. 8-14, 2016.

[21] Council for the Evaluation Accreditation and Quality Assurance of Higher Education of Ecuador, "Results of the current accreditation and categorization," CEAACES, 2016. [Online]. Available: http://www.ceaaces.gob.ec/sitio/acreditacion-y-categorizacion/. [Accessed: 27-Oct-2017].

[22] Escuela Politécnica Nacional, "Electrical engineering program," $E P N$, 2017. [Online]. Available:

http://www.epn.edu.ec/electricidad/. [Accessed: 01-Nov-2017].

[23] Escuela Superior Politécnica del Litoral, "Electrical engineering program," ESPOL, 2017. [Online]. Available:

https://www.fiec.espol.edu.ec/es/generalidades-potencia. [Accessed 01-Nov-2017].

[24] Universidad Católica de Cuenca, "Electrical engineering program," $U C C$, 2018. [Online]. Available:

http://www.ucacue.edu.ec/pregrado/unidad-academica-de-

ingenieria-industria-y-construccion/carrera-de-

electricidad/\#1484690143624-5b5c546c-3d91. [Accessed: 01-Nov2017].

[25] Universidad de Cuenca, "Electrical engineering program," $U d C$, 2017. [Online]. Available: https://www.ucuenca.edu.ec/la-ofertaacademica/oferta-de-grado/facultad-de-ingenieria/carreras/ing-elect. [Accessed: 01-Nov-2017].

[26] Universidad Laica Eloy Alfaro de Manabí, "Electrical engineering program," ULEAM, 2017. [Online]. Available:

http://carreras.uleam.edu.ec/ingenieria/descripcion-de-la-carrera-deingenieria-electrica/. [Accessed: 01-Nov-2017].

[27] Universidad Politécnica Salesiana, "Electrical engineering program," UPS, 2016. [Online]. Available:

https://www.ups.edu.ec/electricidad-guayaquil. [Accessed: 01-Nov2017].

[28] Universidad Técnica de Cotopaxi, "Electrical engineering program," UTC, 2018. [Online]. Available: http://www.utc.edu.ec/electrica. [Accessed: 01-Nov-2017].

[29] Universidad Técnica de Manabí, "Electrical engineering program," UTM, 2017. [Online]. Available: http://www.utm.edu.ec/fcm/. [Accessed: 01-Nov-2017].

[30] Universidad Técnica Estatal de Quevedo, "Electrical engineering program," UTEQ, 2018. [Online]. Available: http://www.uteq.edu.ec/carrera/Ingeniería en Electricidad-4/. [Accessed: 01-Nov-2017].

[31] Universidad Técnica Luis Vargas Torres, "Electrical engineering program," UTLVT, 2016. [Online]. Available: http://utelvt.edu.ec/sitioweb/index.php/carrera-

ingenierias\#ingeniería-eléctrica. [Accessed: 01-Nov-2017].

[32] T. White, L. D. Scott Jr, and M. R. Munson, "Extracurricular activity participation and educational outcomes among older youth transitioning from foster care," Child. Youth Serv. Rev., vol. 85, pp. $1-8,2018$

[33] E. Sinakou, J. Boeve-de Pauw, M. Goossens, and P. Van Petegem, "Academics in the field of Education for Sustainable Development: Their conceptions of sustainable development," J. Clean. Prod., vol. 184, pp. 321-332, 2018.

[34] L. G. Huettel, "A Grand Challenge-based Framework for Contextual Learning in Engineer- ing A Grand Challenge-based Framework for Contextual Learning in Engineering Abstract," ASEE Annu. Conf. Expo., no. 1, 2013.

[35] M. Sufian and A. Karim, "Entrepreneurship Education In An Engineering Curriculum," Procedia Econ. Financ., vol. 35, no. October 2015, pp. 379-387, 2016

[36] S. I. Olsen, P. Fantke, A. Laurent, M. Birkved, N. Bey, and M. Z Hauschild, "Sustainability and LCA in engineering education - A course curriculum," Procedia CIRP, vol. 69, no. May, pp. 627-632, 2018

[37] C. Reyes-lopez and E. González-Martínez, "Feasibility Assessment on the Implementation of M- Learning at Universidad Politecnica Salesiana at Guayaquil,”2017, no. July, pp. 19-21.

[38] H. Friman, "New Trends in the Higher Education: Renewable Energy at the Faculty of Electrical Engineering," Energy Procedia, vol. 115, pp. 18-28, 2017.

[39] H. Mälkki, K. Alanne, and L. Hirsto, "A method to quantify the integration of renewable energy and sustainability in energy degree programmes: A Finnish case study," J. Clean. Prod., vol. 106, pp. 239-246, 2015.

[40] A. Kumar and R. Parashar, "Innovations and Curriculum Development for Engineering Education and Research in India," vol. 56, no. Ictlhe, pp. 685-690, 2012.

[41] E. Soare, "Curricular approach of education . Effects on evaluation design,” Procedia - Soc. Behav. Sci., vol. 76, pp. 775-779, 2013.

$17^{\text {th }}$ LACCEI International Multi-Conference for Engineering, Education, and Technology: "Industry, Innovation, And Infrastructure for Sustainable Cities and Communities", 24-26 July 2019, Jamaica. 